\title{
The Use and Material Development of Audio-Visual Media on www.marmiton.org Website in French Listening Skill
}

\author{
Isda Pramuniati ${ }^{1}$, Marice $^{2}$, Wahyuni Sa'dah ${ }^{3}$ \\ Jurusan Bahasa Asing, FBS, Universitas Negeri Medan, Indonesia \\ J1. Willem Iskandar Pasar V - Kotak Pos No. 1589 - Medan 20221 ${ }^{1}$ \\ $\left\{\text { pramuniatiisda@gmail.com }{ }^{1}\right\}^{1,2,3}$
}

\begin{abstract}
Listening learning (production orale) based on e-learning by utilizing the website www.marmiton.org includes recipes in French to train students' understanding in vocabulary mastery and listening skills. This learning media is taught in an audio-visual manner that contains two language skills, namely reading and listening. This learning media is one of the supporters of the teaching and learning process which is very varied. This study aims to (1) describe the steps in the application of audio-visual media on the www.marmiton.org website in learning the listening skills of French, and (2) describe the feasibility of the material and the development of audio-visual media material on the www.marmiton.org website in learning French listening skills, and (3) describing student learning outcomes using audio-visual media on the www.marmiton.org website in learning French listening skills. The method used in this study is a pre-experimental method with one shot case study research design. The sample of the study is consisted of 30 students of the French Education Program, in the Language and Arts Faculty, UNIMED. The data was obtained through observation during the learning process took place, showing that $75 \%$ of the students were very interested in using this learning strategy because they could clearly see the form of the ingredients accompanied by new terms and vocabulary in French-language recipes.
\end{abstract}

Keywords: Development, audio visual media, listening

\section{1}

\section{Introduction}

The progress that continues to develop in the world of modern information and technology now influences the introduction of regional or cultural characteristics so that the pace of tourism in Indonesia is increasing. This can be seen by the large number of foreign tourists who are interested in Indonesia so that they come to Indonesia for travel or work and stay in Indonesia which they recognize based on the technology that is developing at this time. According to the official Indonesian Central Bureau of Statistics website, the number of foreign tourist arrivals to Indonesia in February 2018 rose by 17.36 percent compared to the number of visits in February 2017, from 1.02 million visits to 1.20 million visits. Based on these statistical data, it can be concluded that the world of Indonesian tourism is developing very rapidly and of course the Indonesian people are required to be proficient in foreign languages so that they can become guides who can improve the economy. Therefore, foreign language learning is very necessary, especially foreign languages for tourism. One foreign language that can be learned is French. 
In language learning, learners can learn four language skills, namely: listening, speaking, reading and writing. Among the four language skills, listening skills are very important language skills, this is because listening skills can make learners know and understand what is the purpose of communication. In terms of listening skills, especially listening in French, learners will be required to understand what they see to get clear information in order to establish good communication.

The teaching of Français pour Objectif Spécifique (FOS) in the French Study Program studied several fields, such as the secretariat, banking, hospitality, restaurant and French culture. For students of language education, listening is not something that is rarely learned, in the field of restaurants in particular. Students tend to listen because there are many menus and ingredients that they must understand come from France. They must learn about typical French food recipes found in various media, both in print media such as recipe books, radio and video tutorial media that are available from various internet pages which certainly require listening skills to get clear information about the recipes they want to learn. But this research will also develop the material of the page by referring to culinary that has the peculiarities of North Sumatra.

Along with video tutorials that are often performed by learners, there are obstacles in translating new vocabulary from the original language into the source language. This makes the instructors required to be able to make learners interested in learning. Difficulties are not only experienced by learners but the same as faced by teachers, especially in delivering learning material to be more easily understood. Being a teacher is required to be creative and full of innovation so that it can stimulate learners to be more active in learning activities. One way that can be done by the teacher is to use learning media that can attract the attention of learners. Audio-visual media are media that contain sound elements called "audio" and elements of "visual" images.

Based on the scores obtained by students on listening skills, the competence of third semester students was still below average, especially in listening skills. The following are student learning outcomes on listening skills.

Table 1. Student Competencies in Listening Skills

\begin{tabular}{ccccc}
\hline Students & $\begin{array}{c}\text { Mid-term } \\
\text { test score }\end{array}$ & $\begin{array}{c}\text { Number } \\
\text { of } \\
\text { Students } \\
(\boldsymbol{\%})\end{array}$ & $\begin{array}{c}\text { Final test } \\
\text { score }\end{array}$ & $\begin{array}{c}\text { Number of } \\
\text { Students } \\
(\%)\end{array}$ \\
\hline Semester 3 & $80-100$ & 20 & $80-100$ & 20 \\
& $70-79$ & 40 & $70-79$ & 40 \\
& $60-69$ & 30 & $60-69$ & 30 \\
& $\ldots-59$ & 10 & $10-59$ & 10 \\
\hline
\end{tabular}

Based on the above scores, the authors developed technology-based learning media supported by the KKNI curriculum that has now been applied at Medan State University, which requires the use of technology according to the concepts and principles of learning. Therefore, the development of listening listening media is expected to improve listening skills.

This media has more capabilities, because audio-visual media relies on two senses at once, namely the sense of hearing and the sense of sight. With these media, it is hoped that it can generate motivation in learning and clarify the material presented. Audio-visual media that 
is often found in daily activities in the form of cooking videos contained in a page. Without realizing it, videos that are often watched like cooking shows can be a learning medium. This certainly can help learners to learn more effectively.

\section{$2 \quad$ Literature Review}

\subsection{Learning Media}

Learning media is a tool for teaching and learning. That is everything that can be used to stimulate the mind, feelings, attention and abilities or skills of students so that it can encourage the learning process in students (students / students). According to Rayanda Asyar (2012: 8) Learning media can be understood as everything that can deliver or channel messages from sources in a planned manner, resulting in a conducive learning environment where the recipient can do the learning process efficiently and effectively, while Munadi (2008: 7) giving understanding that learning media is everything that can deliver and channel messages from sources in a planned manner so as to create a conducive learning environment where the recipient can carry out the learning process efficiently and effectively.

\subsubsection{Benefits of Learning Media}

According to Arief, et al (2009: 17) learning media have the following benefits:

1. Clarify the presentation of a message so that it is not too verbalistic

2. Overcoming the limitations of space, time and sensory power

3. Using learning media appropriately and varied can overcome students' passive attitude. In this case the learning media is useful for:

- arousing learning passion.

- allows direct interaction between students and the environment and reality.

- allows students to learn by themselves according to their interests and abilities.

4. With the unique nature of students as well as different environments and experiences, while the curriculum and materials are the same for each student, this problem can be overcome by learning media in their abilities:

- give the same stimulant.

- equate experience.

- raises the same perception

\subsection{The www.marmiton.org Website as an Alternative Learning Media}

The www.marmiton.org page is a site page that functions as an audio-visual about recipes that are packaged in French. The page entitled "marmiton" is a noun that comes from the French language itself and has a meaning as "cook". On the page www.marmiton.org there are various recipes that are available in French and certainly can be a medium of learning, because through the language that is heard and read, the page becomes a good learning media, especially for French learners. In this case, researchers used the page www.marmiton.org as a learning medium to test language skills listening to students of the French Language Education Program, Language and Arts Faculty, Unimed. 


\subsection{Listening as a Language Skill}

\subsubsection{Definition of Listening}

Listening skills are part of language skills that are essential, because listening skills are the basis for mastering a language. Young children who begin to learn language, begin by listening to the series of sounds they hear, learning to imitate, then try to apply them in conversation. After entering school, the child learns to read from recognizing the letter or sound of the language shown by the teacher to say the sounds of language or the activity of imitating the sounds of the language. In this situation, the child has begun to write. And so on until the child can express the contents of the mind through both oral and written language, and be able to understand the contents of other people's thoughts expressed through both spoken and written language.

Listening or listening is a skill to understand spoken language that is receptive or accepting. as stated by Brooks in Tarigan (2008: 4) that listening means receiving information from verbal sources or in other words listening means receiving information from speaking activities.

According to Heryadi (2008: 7), "Listening activities are actions or mental activities in capturing, understanding, weighing, and responding to messages contained in symbols of oral language"

\section{Methodology}

The method used in this research is education and development research or often known as Research and Development (R \& D). This research uses research and development methods or commonly referred to as Research and Development. Sugiyono (2011: 297) states that Research and Development is a research method used to produce certain products, and then tests the effectiveness of these products.

Borg and Gall (1979: 772) stated that "R \& D processes are used to develop and validate educational products." Based on these definitions, this research relies on efforts to produce and validate an educational model namely Audio-Visual Media on the www.marmitonpage.org website in French Language Listening Skills Learning.

Borg and Gall further explained that what is meant by educator products include two types, namely in the form of material objects, such as textbooks, films for teaching, and so on as well as building procedures and processes, such as teaching methods or organizational methods of teaching. The form can be in the form of learning goals, methods, curriculum, and evaluation, both hardware and software, both the method and procedure.

Based on this understanding researchers want to do this type of $\mathrm{R} \& \mathrm{D}$ research to develop a teaching material in contextual learning. The teaching material is based on contextual learning using procedural development models. Setyosari, (2015: 284) procedural model is a descriptive model that describes the flow or procedural steps that must be followed to produce a particular product.

In this study, the researchers wanted to describe the steps in developing Media AudioVisual on the www.marmiton.org page in French Language Listening Skills Learning. Therefore researchers used procedural models. Audio-Visual Media on the 
www.marmiton.org website will be tested on students of the French Education Study Program of the Language and Arts Faculty, UNIMED. 


\subsection{Research Procedure}

The developed media were analyzed using the validation of the material expert team and media design and assessment using rubrics developed by researchers by modifying expert opinions. Criteria for teaching materials based on the suitability criteria of Media AudioVisual on the www.marmiton.orgwebsite in French Listening Skills Learning.

\subsection{Research Location}

Research location is a place used by researchers to conduct research. The location used in this study is the French Education Study Program, Language and Arts Faculty, Medan State University.

\subsection{Draft Audio-Visual Media Development}

The researcher adapted the development applied by Borg and Gall with the reason that the development plan had the aim of developing and validating the product. Visual Media Development is programmatically prepared with preparation and planning in the following steps:

1. Research and information gathering

2. Planning Development of Audio-Visual Media Media on www.marmiton.org website in French Listening Skills Learning

3. Develop preliminary forms of Media Audio-Visual products.

4. Trial (Expert Validation)

a. Limited Field Test

b. Field Test

5. Revision I of the Main product based on expert validator advice

6. Upload Network

\section{Discussion}

In accordance with the purpose of the study, to develop learning media through audiovisual media and to produce a media. As the basic material of the media is data related to listening skills supported by audio-visual media on the page www.marmiton.org. The discussion of this paper contains the results of data collection and then mapped in the table. The preliminary data presented are related to KD-GPA and Material as follows.

Table 2. Mapping of KD, GPA, Material A2

\begin{tabular}{|c|c|c|}
\hline Basic Competence & Indicators of Competence Achievement & Material \\
\hline $\begin{array}{l}\text { Able to understand } \\
\text { meaningful words and } \\
\text { phrases related to }\end{array}$ & $\begin{array}{l}\text { Understand the words related to recipes } \\
\text { Understand the phrases related to recipes } \\
\text { Able to do a cooking recipe demo } \\
\text { Able to explain things related to recipes. } \\
\text { Able to understand words related to recipes } \\
\text { in French A2 level }\end{array}$ & $\begin{array}{l}\text { 1. Video resep } \\
\text { masakan } \\
\text { Prancis }\end{array}$ \\
\hline
\end{tabular}


The material contained in the table above is the second material in listening learning. The data needed in pedagogic elements are indicators and materials that will be developed and require knowledge in understanding the vocabulary contained in an audio-visual so that it can be practiced according to the indicators to be achieved.

\section{Conclusion}

This paper is the result of the initial data collection which still contains the content features of the teaching materials to be developed. In one chapter there are Basic Competencies and five Indicators of Achievement of Competence. Based on audio-visuals on the www.marmiton.org page, it will be filled with local cultural recipes in French that will increase knowledge about new vocabulary and innovation for students in learning listening skills.

\section{References}

[1] Heryadi, Dedi. Kemahiran Menyimak Teori dan Pembelajaran. Tasikmalaya: Universitas Siliwangi. (2008).

[2] Tarigan, Henry Guntur. Menyimak Sebagai Suatu Keterampilan Berbahasa. Bandung: Angkasa. (2008).

[3] Mudjianto dan Susanto, Gatut. Materi Pembelajaran Menyimak. Malang: A3 Malang. (2010).

[4] Hermawan, Herry. Menyimak Keterampilan Berkomunikasi yang Terabaikan. Yogyakarta : Graha Ilmu. (2012).

[5] Asyhar, Rayandra. Kreatif Mengembangkan Media Pembelajaran. Jakarta: Referensi Jakarta. (2012).

[6] Munadi, Y, Media Pembelajaran, Jakarta: Gaung Persada Press. (2008).

[7] Kuswanto, Goto. Pemanfaatan Media Pembelajaran untuk Meningkatkan Efektivitas Diklat oleh Widyaiswara. [Online]. Tersedia: http://diklatbanyumas.blogspot.com/2012/03/pemanfaatan-mediapembelajaran-untuk.html [08 April 2018]. (2012).

[8] Sadiman, Arief S. dkk. Media Pendidikan : Pengertian, Pegembangan dan Pemanfaatannya. Jakarta : Raja Grafindo Persada. (2009).

[9] Supriatna, Dadang. Pengenalan Media Pembelajaran. Pusat Pengembangan Dan Pemberdayaan Pendidik Dan Tenaga Kependidikan Taman Kanak Kanak Dan Pendidikan Luar Biasa. (2009).

[10] Arikunto, S. Prosedur Penelitian: Suatu Pendekatan Praktek, Jakarta: PT. Rineka Cipta. (2006).

[11] Asnawir, H. dan Usman, M. Basyirudin. 2002. Media Pembelajaran. Ciputat Pers Jakarta.

[12] Chauvet, A. Référentiel pour le Carde Européen Commun Paris:. CLE.

Direktorat Akademik. 2013. Panduan Program Pengalaman Lapangan (PPL)Kependidikan dan Tenaga Pendidik. Bandung: Universitas PendidikanIndonesia.

Departemen Pendidikan dan Kebudayaan. (2002). Kamus Besar Bahasa Indonesia. Jakarta: Balai Pustaka. (2008).

[13] Djamarah, S. dan Zain, A. Strategi Belajar Mengajar. Jakarta: Rineka Cipta. (2006).

[14] Herman, H. Menyimak: Keterampilan berkomunikasi yang terabaikan. Yogyakarta: Graha Ilmu. (2012).

[15] Nurgiyantoro, B. Penilaian dalam Pengajaran Bahasa dan SastraIndonesia. Yogyakarta: $\operatorname{BPFE}(2010)$.

[16] Rey, A. Le Robert Micro: Dictionnaire d'Apprentissage de la langue Français. Paris: Le Robert. (2006).

[17] Sanjaya, W. Perencanaan dan DesignSistem Pembelajaran. Jakarta:Kencana. (2008). 
[18] Setiadi, R. Analisis dan Interpretasi Data melalui Pendekatan Kuantitatifdan Kualitatif. Bandung: Bahan Ajar mata Kuliah Metodologi Penelitian. (2010).

[19] Sudjana, N. Metodologi Pengajaran. Bandung : Sinar Baru. (2001).

[20] Sudjana, N. Penelitian Hasil Proses Belajar Mengajar. Bandung: PT. Remaja Rosdakarya. (2005).

[21] Sudjana, N. dan Ibrahim. Penelitian dan Penilaian Pendidikan. Bandung :Sinar Baru Algensindo. (2004).

[22] Sudjana N. dan Rivai A. Media Pengajaran. Bandung: Sinar Baru Algesindo. (2007),

[23] Sugiyono. Metode Penelitian Pendidikan Pendekatan Kuantitatif,Kualitatif, dan R\&D. Bandung:

Alfabeta. (2011).

[24] Susilana, R. dan Riyana, C. Media Pembelajaran. Bandung: Tidak Diterbitkan. (2008).

[25] Tarigan, H. Menyimak sebagai Suatu Keterampilan Berbahasa. Bandung: Angkasa. (2008). 